\title{
Atrazine treatment with heterogeneous photo-Fenton like oxidation using statically approach
}

\section{İstatistiksel yaklaşım kullanarak heterojen foto-Fenton benzeri oksidasyon ile atrazin arıtımı}

\author{
Ebru ÇOKAY1* \\ ${ }^{1}$ Department of Environmental Engineering, Engineering Faculty, Dokuz Eylul University, Izmir, Turkey. \\ ebru.cokay@deu.edu.tr
}

Received/Geliş Tarihi: 11.09.2018, Accepted/Kabul Tarihi: 20.12.2018

* Corresponding author/Yazıșılan Yazar

doi: $10.5505 /$ pajes.2018.20633

Research Article/Araștırma Makalesi

\begin{abstract}
Atrazine (ATZ) which is a triazine herbicide can be used for the control weeds on agricultural land and it is classified as an endocrine disrupting pesticide. ATZ is persistent in water and soil due to its halflife and slow degradation by means of sunlight and microorganism. The heterogeneous Fenton process is an effective technique for degrading atrazine because of the oxidation and adsorption of pollutants by hydroxyl radical. The hydroxyl radical formation has been accelerated by addition of hydrogen peroxide and magnetite. heterogeneous Photo-Fenton like oxidation were executed to remove atrazine in this study. Effects of independent variables namely the concentrations of atrazine, hydrogen peroxide and magnetite on atrazine removal efficiency were investigated by using the surface response analysis. Atrazine degradation was completely achieved with an hour. Optimal $\mathrm{H}_{2} \mathrm{O}_{2} /$ Magnetite/ATZ ratio resulting by optimum atrazine removal efficiency (97.5\%) was determined as 10/5/0.7, respectively.
\end{abstract}

Keywords: Atrazine, Heterogeneous photo-fenton like oxidation, Box-Behnken
Öz

Atrazin (ATZ) triazin herbisit olup tarım arazileri üzerindeki kontrol bitkileri için kullanılmaktadır. Endokrin bozucu bir pestisit olarak sınıflandırılmaktadır. ATZ, yarı ömrnün uzun olması, güneș ıșığı ve mikroorganizma ile parçalanması yavaș olması nedeni ile nedeniyle su ve toprakta kalıcıdır. Heterojen Fenton prosesi ile kirletici maddelerin hidroksil radikali ile oksitlenmesi ve adsorpsiyonu mümkün olup atrazinin parçalanması için etkili bir yöntemdir. Hidroksil radikal olușumu hidrojen peroksit ve manyetit kullanımı ile artırılabilmektedir. Bu çalışmada atrazini giderebilmek için heterojen Foto-Fenton benzeri oksidasyon yöntemi uygulanmiștır. İstatiksel yöntemi olan yüzey yanit yönteminde; atrazin, hidrojen peroksit ve manyetit konsantrasyonlarının bağımsız değișkenlerin atrazin giderme verimi üzerindeki etkileri araștırılmıștır. Atrazinin tamamen parçalanması bir saatlik reaksiyon süresinde gerçekleștirilmiştir. Optimum $\mathrm{H}_{2} \mathrm{O}_{2}$ /Manyetit/ATZ oranı 10/5/0.7 olarak belirlenmiștir ve optimum oranda atrazin giderme verimi \%97.5 olarak elde edilmiștir.

Anahtar kelimeler: Atrazin, Heterojen foto-fenton benzeri oksidasyon, Box-Behnken

\section{Introduction}

Atrazine (ATZ) which is a triazine herbicide can be applied to the control broadleaf and grassy weeds on agricultural land and it is classified as an endocrine disrupting pesticide [1],[2]. Due to endocrine disrupting properties, atrazine affects the human body and hormones.

Atrazine's biodegradability is low and it moderately solubles in water. It does not adsorb strongly to sediments. It can be seen generally in aquatic life. The atrazine concentration can be changed in aquatic life depending on treatment plant operating conditions and ATZ's concentration generally shows considerable fluctuation. Atrazine's half-life in the surface water resources changes from 41 to 237 days and its half-life in groundwater resources ranges from 15 months to 20 years [3]. The maximum atrazine concentration in drinking water is permitted by the USEPA and WHO is 3.0 and $2.0 \mu \mathrm{g} / \mathrm{L}$, respectively [4]. According to researches, ATZ was listed in priority substances by the European Union the Directive 2013/39/EU. In spite of being banned, it has been still in use in some countries such as North America and China. Atrazine formula and properties are also presented in Table 1.

The treatment of atrazine has gain more importance in recent years due to toxicity and low biodegradability. Photolysis of atrazine in water under sunlight occurs in a half life 335 days. Photolysis of atrazine did not realize with wavelengths greater than $300 \mathrm{~nm}$. ATZ is persistent in water and soil due to its halflife and slow degradation by means of sunlight and microorganism. Atrazine cannot be treated by biological methods due to its resistant to microorganism for degradation. In addition, it has been known to inhibit the microorganism activity in biological treatment unit. For that reason, new technologies should be used for the treatment of atrazine in order to improve of its degradation or to remove it before discharging into the environment [5]. Conventional treatment processes can be used for ATZ removal. However, atrazine cannot be treated with these methods and ATZ degradation may be improved by oxidation processes such as AOPS.

Table 1: Atrazine properties.

\begin{tabular}{cc}
\hline CAS Number & $1912-24-9$ \\
\hline Molecular weight & $215.7 \mathrm{~g} / \mathrm{mole}$ \\
Molecular Formula & $\mathrm{C}_{8} \mathrm{H}_{14} \mathrm{~N}_{5} \mathrm{Cl}$ \\
Water Solubility & $33 \mathrm{mg} / \mathrm{L} \mathrm{at} \mathrm{pH} 7$ \\
Vapor Pressure & $2.89^{*} 10^{-7} \mathrm{~mm} \mathrm{Hg} \mathrm{@} 25{ }^{\circ} \mathrm{C}$ \\
Solubility in organic solvent & $18000 \mathrm{mg} / \mathrm{L} \mathrm{in} \mathrm{methanol}$ \\
Log Kow & $2.68 @ 25{ }^{\circ} \mathrm{C}$ \\
\hline
\end{tabular}

Refractory and toxic organic compounds can be degraded or mineralized by advanced oxidation processes (AOPs) known as effective and useful process, because these processes can produce hydroxyl radical which is a nonselective and most 
powerful oxidant (2.8 V). Hydroxyl radicals can react faster than the other oxidants in oxidation process. Fenton process has been known as one of the most effective methods in all AOP methods to degrade and mineralize the organic compounds in wastewater. Generally, classical Fenton process and homogeneous Photo-Fenton process can be used to treat refractory, toxic and not biodegradable compounds. Atrazine can be easily degraded by using Fenton-based processes. In one study, atrazine was treated by Fenton process and atrazine which was changed to $0.1 \mathrm{mg} / \mathrm{L}$ from $100 \mathrm{mg} / \mathrm{L}$ was treated with $\mathrm{H}_{2} \mathrm{O}_{2}(5-50 \mathrm{mg} / \mathrm{L})$ and iron 1-55 mg/L [6]. Unfortunately, there are some disadvantages in classic Fenton process: first of all, ferric ions should be separated after the treatment and this situation makes the Fenton process uneconomic and not preferable. Other disadvantage of Fenton process is that this process only works acidic conditions such as $\mathrm{pH}$ 3.5. This situation restricts the reaction conditions and does not desirable. In order to deal with some obstacles according to homogeneous Fenton process, the Fenton-like or heterogeneous Fenton process, in which soluble ferric or ferrous ions are changed by Fe-containing solids like magnetite, hematite, goethite and soon have been recently investigated.

The heterogeneous Fenton process is an effective method to degrade atrazine [6] because of the oxidation of pollutants by - $\mathrm{OH}$ radical. In some studies, heterogeneous Photo-Fenton method was more useful and effective than heterogeneous photo-catalysis to degrade and mineralize the pesticide [7]-[9]. The hydroxyl radical formation $(\cdot \mathrm{OH})$ has been demonstrated to be $\mathrm{H}_{2} \mathrm{O}_{2}$ and magnetite. The significant advantage of heterogeneous Fenton-like process over the classic Fenton oxidation is that heterogeneous Fenton-like process occurs at all $\mathrm{pH}$ values. Magnetite and pyrite are the most effective iron oxides as compared to the others because of the Fe (II) and Fe (III) in their structure, which accelerates the rate of formation $\cdot \mathrm{OH}[10]$.

Magnetite $\left(\mathrm{Fe}_{3} \mathrm{O}_{4}\right)$ which is an efficient solid catalyst has generally selected as an iron catalyst in heterogeneous Fenton-like or heterogeneous Photo Fenton-like process. Magnetite $\left(\mathrm{Fe}_{3} \mathrm{O}_{4}\right)$ has cubic inverse spinal structure. Its chemical formula can be written as $\mathrm{Fe}_{3} \mathrm{O}_{4}$ [11]. Chemical structure of magnetite is given in Figure 1.

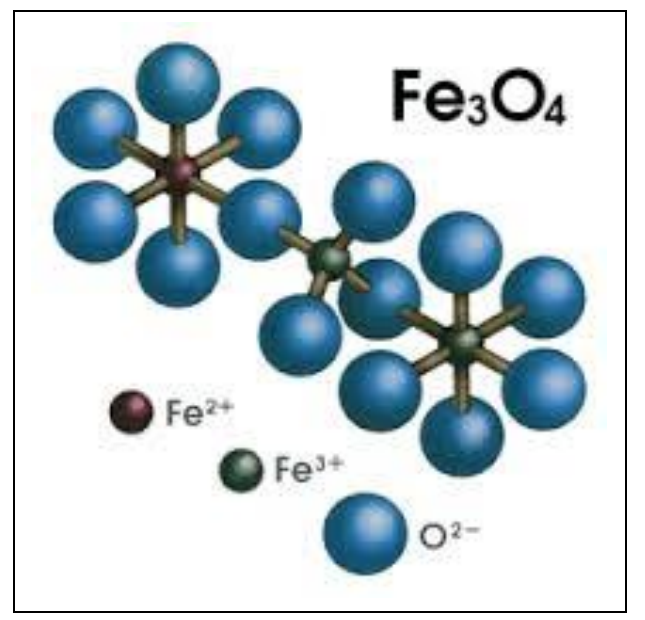

Figure 1: Magnetite structure.

In the Fenton process, magnetite shows some several properties: (1) magnetite contains $\mathrm{Fe}^{2+}$ which initiate the Fenton mechanism and this reaction is necessary to continue the Fenton reaction; (2) magnetite also contains both $\mathrm{Fe}^{2+}$ and $\mathrm{Fe}^{3+}$, ferric and ferrous ions can be reversibly react with pollutants to oxidize; and (3) $\mathrm{Fe}_{3} \mathrm{O}_{4}$ has peroxides-like activity which can active $\mathrm{H}_{2} \mathrm{O}_{2}$. Magnetite $\left(\mathrm{Fe}_{3} \mathrm{O}_{4}\right)$ is an excellent catalyst for advanced oxidation processes due to catalytic activity and redox properties. Magnetic separation can be used to separate magnetite in wastewater after the reaction.

\subsection{Design of experiments}

Generally, one factor in multivariable systems altered at a time to observe effects of variables. However, this approach cannot give useful or predictable responses. For that reason, nowadays, experimental statically design should be advised to optimize the reaction conditions. Response surface methodology called as RSM is generally chosen. This design contains 3-level factorial design, central composite design [12],[13], Box-Behnken design [14]. Between all response surface designs, Box-Behnken design requires fewer experimental runs. In addition, this design demonstrates to removal efficiency at variable concentrations which were not conducted experimentally [15],[16]. In this study, advanced oxidation process (heterogeneous Photo-Fenton like process) applied to evaluate atrazine oxidation and degradation according to atrazine removal efficiency. The effects of initial atrazine, magnetite and $\mathrm{H}_{2} \mathrm{O}_{2}$ concentrations on atrazine removal efficiency were studied by means of Box-Behnken method. The most favorable concentrations of independent variables for the atrazine treatment were determined by statistically as a main objective of this study. Although, Fenton process can be preferred using Box-Behnken method to treat some wastewaters, Heterogeneous Photo-Fenton like method especially using magnetite is not executed to treat a special micropollutant which is banned from European committee in Europe and this micropollutant cannot be treated easily by biological methods. For that reason, this study presents new experimental idea and results.

\section{Material and method}

\subsection{Analytical methods}

Atrazine $\left(\mathrm{C}_{8} \mathrm{H}_{14} \mathrm{~N}_{5} \mathrm{Cl}\right)$ was purchased from TCI. Atrazine analyses were done by Thermo Scientific TSQ Quantum MAX LC MSMS. Reaction conditions of LC/MS/MS; Injection Volume:25 ul, MS Acquire Time:15 min, İyon source ESI (+). Mobile Phase of atrazine analyses using LC/MS/MS; Mobile Phase A: $\% 95 \mathrm{H}_{2} \mathrm{O} \% 5 \mathrm{MeOH}, 4 \mathrm{mM}$ Amonnium Formate, \%0.1 Formic Acid. Mobile Phase B: $\% 95 \mathrm{MeOH} \% 5 \mathrm{H}_{2} \mathrm{O}, 4 \mathrm{mM}$ Amonnium Formate, \%0.1 Formic Acid. Atrazine concentrations between $25 \mathrm{ppb}$ and $1000 \mathrm{ppb}$ were used to determine calibration curve with a linearity of $\mathrm{R}^{2}=0.974$. Hydrogen peroxide as an oxidant $(35 \% \mathrm{w} / \mathrm{w})$ was used and obtained from Merck. In the heterogeneous Photo-Fenton like oxidation, magnetite as a source of iron was used and purchased from Merck (\%99).

\subsection{Experimental procedure}

Heterogeneous Photo-Fenton like oxidation was executed at room temperature $\left(23 \pm 2{ }^{\circ} \mathrm{C}\right)$ with different magnetite and $\mathrm{H}_{2} \mathrm{O}_{2}$ concentration which were determined by statistical program.

Concentration of atrazine was changed to $0.1 \mathrm{mg} / \mathrm{L}$ from $1 \mathrm{mg} / \mathrm{L}$. pH of wastewater was adjusted with sulfuric acid solution addition at $\mathrm{pH} 3.5$. Thermo scientific Orion $\mathrm{pH}$ meter $720 \mathrm{a}$ was used to measure $\mathrm{pH}$ of wastewater. 
After $\mathrm{pH}$ adjustment of wastewater, magnetite (catalyst) was added and mixed well. Then, hydrogen peroxide (oxidant) was added to reactor. The UV lamp was opened up as soon as possible. At this time was accepted as the beginning of the experiment or time zero. At the determined times, samples were taken from the reactor to evaluate atrazine removal and $\mathrm{pH}$ variations. Raw and treated atrazine samples were centrifuged to prevent clogging in LC/MS/MS column and immediately analyzed to avoid some reactions.

\section{$2.3 \quad$ Experimental set-up}

Heterogeneous Photo-Fenton like oxidation experiments were conducted in the photochemical reactor which was given in Figure 2. Photochemical reactor is made of glass and its volume is $2.2 \mathrm{~L}$. In order to protect eyes and overcome leakage from UV lamp to outside, the reactor was shrouded with an aluminum foil. A photochemical reactor includes some ports to feed oxidant and catalyst, sample removals, to measure temperature and to withdraw samples. The reactor was placed on a magnetic stirrer to provide a proper mixing with a stirring bar.

UV lamp was axially centered and placed in a quartz tube. UV lamp properties are a $16 \mathrm{~W}$ low-pressure mercury vapor lamp and maximum emission at $254 \mathrm{~nm}$. The UV radiation intensity was determined as $4.98^{*} 10^{-6}$ einstein/s via ferrioxalate actinometry method. The UV lamp was placed in a watercooling jacket to adjust temperature and execute runs at room temperatures, because of production heat from the light source.

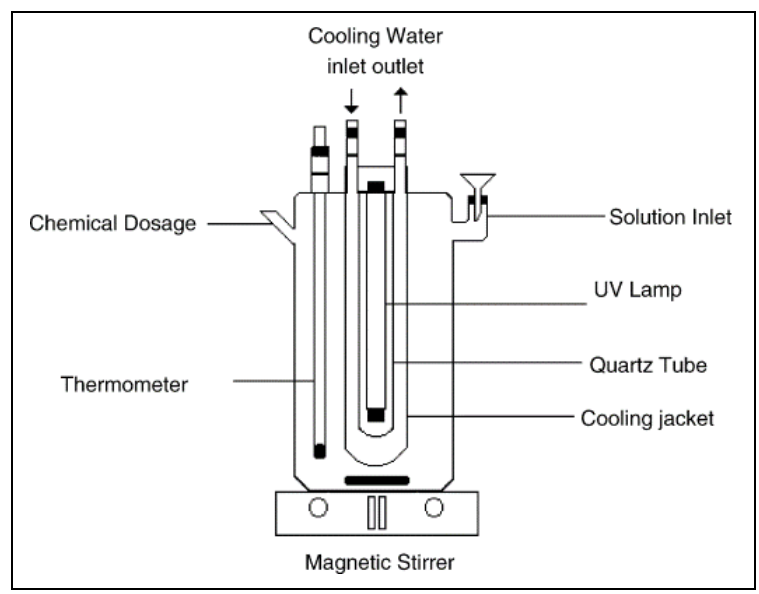

Figure 2: Schematic diagram of UV reactor.

\section{Results and discussion}

Atrazine $\left(\mathrm{X}_{1}\right), \mathrm{H}_{2} \mathrm{O}_{2}\left(\mathrm{X}_{2}\right)$ and magnetite $\left(\mathrm{X}_{3}\right)$ as the independent variables were chosen in design. In addition, percent atrazine removal $\left(\mathrm{Y}_{1}\right)$ as a dependent variable (or objective function) was chosen in Box-Behnken design. The low (-1), center (0) and high $(+1)$ levels of each variable determined by statically approach were shown in Table 2.

Table 2: Levels of variables in Box-Behnken design.

\begin{tabular}{ccccc}
\hline Variable & Symbol & $\begin{array}{c}\text { Low } \\
(-1)\end{array}$ & $\begin{array}{c}\text { Center } \\
(0)\end{array}$ & $\begin{array}{c}\text { High } \\
(+1)\end{array}$ \\
\hline Atrazine $(\mathrm{mg} / \mathrm{L})$ & $\mathrm{X}_{1}$ & 0.1 & 0.55 & 1 \\
$\mathrm{H}_{2} \mathrm{O}_{2}(\mathrm{mg} / \mathrm{L})$ & $\mathrm{X}_{2}$ & 0 & 5 & 10 \\
Magnetite $(\mathrm{mg} / \mathrm{L})$ & $\mathrm{X}_{3}$ & 0 & 2.5 & 5 \\
\hline
\end{tabular}

While initial atrazine concentration $\left(X_{1}\right)$ varied between 0.1 and $1 \mathrm{mg} / \mathrm{L}$, hydrogen peroxide concentration $\left(\mathrm{X}_{2}\right)$ altered between 0 and $10 \mathrm{mg} / \mathrm{L}$. The magnetite concentration $\left(\mathrm{X}_{3}\right)$ was ranged from 0 to $5 \mathrm{mg} / \mathrm{L}$. Independent variables effects (atrazine, hydrogen peroxide and magnetite) on objective function (percent atrazine removal) were evaluated. Experimental conditions were selected by means of my previous oxidation studies.

The dependent variable (or objective function) was the percent atrazine removal $\left(\mathrm{Y}_{1}\right)$. Heterogeneous Photo-Fenton like oxidation experiments, designed by Box-Behnken design are given in Table 3. Atrazine removal efficiencies as observed and estimated results via statically design are also given in Table 4.

\subsection{The regression model}

The application of RSM offers an empirical relationship the objective function $(\mathrm{Y})$ and the independent variables $(\mathrm{X})$ can be approximated by a quadratic (second-order) polynomial equation as follows (Eq 1):

$$
\begin{gathered}
Y=b_{0}+b_{1} X_{1}+b_{2} X_{2}+b_{3} X_{3}+b_{12} X_{1} X_{2}+b_{13} X_{1} X_{3}+b_{23} X_{2} X_{3}+ \\
b_{11} X_{1}^{2}+b_{22} X_{2}^{2}+b_{33} X_{3}^{2}
\end{gathered}
$$

This statically design was preferred due to fewer combinations of the independent variables to estimate the second-order polynomial regression model. Coefficients in regression model were determined by means of total of 15 runs. Nine coefficients were calculated such as one block term, three linear terms, three quadratic terms and three interaction terms. The objective function for Atrazine removal efficiencies with the determined coefficient is presented by Eqs. (2).

$$
\begin{gathered}
\mathrm{Y}_{1}=47.91+149.02 \mathrm{X}_{1}+1.43 \mathrm{X}_{2^{-}} \\
6.97 \mathrm{X}_{3}+2.46 \mathrm{X}_{1} \mathrm{X}_{2}+3.91 \mathrm{X}_{1} \mathrm{X}_{3}+0.20 \mathrm{X}_{2} \mathrm{X}_{3}-135.91 \mathrm{X}_{1}^{2}-0.26 \mathrm{X}_{2}{ }^{2} \\
+0.70 \mathrm{X}_{3}{ }^{2}(\mathrm{R}-\text { Squared }=0.992
\end{gathered}
$$

According to the coefficients in Equations (2), it can be that percent ATZ removal efficiency decreases with high amount of magnetite concentrations $\left(\mathrm{X}_{2}\right)$ especially low initial atrazine concentration. The $\mathrm{H}_{2} \mathrm{O}_{2}$ variable has a more significantly effect on atrazine removal efficiency when compared to magnetite independent variable.

Table 5 presents the analysis of variance results which indicate the predictability of the model. Predictions for atrazine removal efficiencies are in good agreement with the observed experimental data. A coefficient of determination $\left(\mathrm{R}^{2}\right)$ is larger than 0.99 . In addition, the computed $\mathrm{F}$ value is much greater than that of the tabular $F_{0.01}$ (14.14) value of 3.70 . This means the treatment is highly significant. $\mathrm{P}$ values of less than 0.05 indicated the effectiveness of independent variables on objective function. $\mathrm{P}$ values were evaluated for all independent variables to determine effectiveness of variables.

\subsection{Removal of atrazine}

Variations of atrazine removal efficiencies with the independent variables (atrazine, magnetite and hydrogen peroxide concentrations) under different reaction conditions were estimated by coefficients determined from statically design. Initial atrazine concentration effects on atrazine removal efficiencies at different $\mathrm{H}_{2} \mathrm{O}_{2}$ concentrations during 60 min of reaction time are shown in Figure 3.

At these reaction conditions, initial magnetite concentration was selected as $5 \mathrm{mg} / \mathrm{L}$. 
Table 3: Heterogeneous Photo-Fenton like oxidation runs designed by statically design.

\begin{tabular}{ccccc}
\hline Run No & Atrazine $(\mathrm{mg} / \mathrm{L})$ & $\mathrm{H}_{2} \mathrm{O}_{2}(\mathrm{mg} / \mathrm{L})$ & Magnetite $(\mathrm{mg} / \mathrm{L})$ & Atrazine Rem. \\
\hline 1 & $0(0.55)$ & $-1(0)$ & $+1(5)$ & 81.40 \\
2 & $+1(1)$ & $+1(10)$ & $0(2.5)$ & 75.30 \\
3 & $0(0.55)$ & $0(5)$ & $0(2.5)$ & 91.20 \\
4 & $-1(0.1)$ & $-1(0)$ & $0(2.5)$ & 49.90 \\
5 & $+1(1)$ & $-1(0)$ & $-1(0)$ & 55.20 \\
6 & $+1(1)$ & $0(5)$ & $0(2.5)$ & 73.90 \\
7 & $0(0.55)$ & $0(5)$ & $0(2.5)$ & 90.45 \\
8 & $-1(0.1)$ & $+1(10)$ & $0(2.5)$ & 47.90 \\
9 & $0(0.55)$ & $0(5)$ & $-1(0)$ & 91.40 \\
10 & $0(0.55)$ & $+1(10)$ & $-1(5)$ & 91.50 \\
11 & $+1(1)$ & $0(5)$ & $-1(0)$ & 84.30 \\
12 & $-1(0.1)$ & $0(5)$ & $+1(5)$ & 60.20 \\
13 & $0(0.55)$ & $-1(0)$ & $+1(5)$ & 51.40 \\
14 & $-1(0.1)$ & $0(5)$ & $+1(10)$ & 91.50 \\
15 & $0(0.55)$ & &
\end{tabular}

Table 4: Atrazine removal efficiencies as observed and predicted results via statically design.

\begin{tabular}{|c|c|c|c|c|c|}
\hline Run No & Atrazine (mg/L) & $\mathrm{H}_{2} \mathrm{O}_{2}(\mathrm{mg} / \mathrm{L})$ & Magnetite (mg/L) & $\begin{array}{l}\text { Predicted ATZ } \\
\text { rem. (\%) }\end{array}$ & $\begin{array}{c}\text { Observed ATZ rem. } \\
(\%)\end{array}$ \\
\hline 1 & 0.55 & 0 & 5 & 81.40 & 82.06 \\
\hline 2 & 1 & 10 & 2.5 & 75.30 & 75.85 \\
\hline 3 & 0.55 & 5 & 2.5 & 91.20 & 91.02 \\
\hline 4 & 0.1 & 0 & 2.5 & 49.90 & 49.35 \\
\hline 5 & 1 & 0 & 2.5 & 55.20 & 57.73 \\
\hline 6 & 1 & 5 & 0 & 73.90 & 74.01 \\
\hline 7 & 0.55 & 5 & 2.5 & 90.45 & 91.02 \\
\hline 8 & 0.1 & 10 & 2.5 & 47.90 & 45.38 \\
\hline 9 & 0.55 & 5 & 2.5 & 91.40 & 91.02 \\
\hline 10 & 0.55 & 10 & 0 & 91.50 & 90.84 \\
\hline 11 & 1 & 5 & 5 & 84.30 & 81.11 \\
\hline 12 & 0.1 & 5 & 0 & 60.20 & 63.39 \\
\hline 13 & 0.55 & 0 & 0 & 91.40 & 88.76 \\
\hline 14 & 0.1 & 5 & 5 & 53.00 & 52.89 \\
\hline 15 & 0.55 & 10 & 5 & 91.50 & 94.14 \\
\hline Source & SS & D.F. & MS & F Value & p-Value \\
\hline Model & 4121.98 & 9 & 458 & 46.74 & 0.0003 \\
\hline A-Atrazine & 754.66 & 1 & 754.66 & 77.02 & 0.0003 \\
\hline $\mathrm{B}-\mathrm{H}_{2} \mathrm{O}_{2}$ & 100.11 & 1 & 100.11 & 10.22 & 0.0241 \\
\hline C-Magnetite & 5.78 & 1 & 5.78 & 0.59 & 0.4772 \\
\hline $\mathrm{AB}$ & 122.10 & 1 & 122.10 & 12.46 & 0.0167 \\
\hline $\mathrm{AC}$ & 77.44 & 1 & 77.44 & 7.90 & 0.0375 \\
\hline $\mathrm{BC}$ & 25.00 & 1 & 25.00 & 2.55 & 0.1711 \\
\hline$A^{\wedge} 2$ & 2796.54 & 1 & 2796.54 & 285.40 & $<0.0001$ \\
\hline $\mathrm{B}^{\wedge} 2$ & 152.22 & 1 & 152.22 & 15.53 & 0.0109 \\
\hline $\mathrm{C}^{\wedge} 2$ & 70.00 & 1 & 70.00 & 7.14 & 0.0442 \\
\hline Residual & 48.99 & 5 & 9.80 & & \\
\hline Lack of Fit & 48.49 & 3 & 16.16 & 64.44 & 0.0153 \\
\hline Pure Error & 0.50 & 2 & 0.25 & & \\
\hline Cor Total & 4170.97 & 14 & & & \\
\hline
\end{tabular}

As shown in Figure 4, atrazine removal efficiencies were 54. 85 and 98\% when Atrazine concentrations of 0.1. 0.7 and 1 $\mathrm{mg} / \mathrm{L}$ respectively at a magnetite concentration of $5 \mathrm{mg} / \mathrm{L}$. As can be seen in Figure 4, hydrogen peroxide requirement to remove atrazine was approximately $7.5 \mathrm{mg} / \mathrm{L}$ at high magnetite concentration. Higher than this concentration, ATZ removal efficiency did not change or decrease. High oxidant concentrations give to low atrazine removal efficiency due to excess oxidant and catalyst usage. In other words, high $\mathrm{H}_{2} \mathrm{O}_{2} / \mathrm{Fe}$ molar ratio produced insufficient removal efficiencies. Free-radical scavenger can be produced by using high $\mathrm{H}_{2} \mathrm{O}_{2}$ concentrations. In addition, probably $\mathrm{H}_{2} \mathrm{O}_{2}$ behavior as an inhibitor for itself reduces the hydroxyl radical.

$\mathrm{OH}^{\bullet}+\mathrm{H}_{2} \mathrm{O}_{2} \rightarrow \mathrm{H}_{2} \mathrm{O}+\mathrm{HO}_{2} \bullet$

$\mathrm{OH}^{\bullet}+\mathrm{HO}_{2} \bullet \rightarrow \mathrm{H}_{2} \mathrm{O}+\mathrm{O}_{2}$ 
Same situation observed in other studies [17], [18]. In one study, pesticide removal efficiencies decreased at high $\mathrm{H}_{2} \mathrm{O}_{2}$ concentrations because of the adverse effects of excess $\mathrm{H}_{2} \mathrm{O}_{2}$.

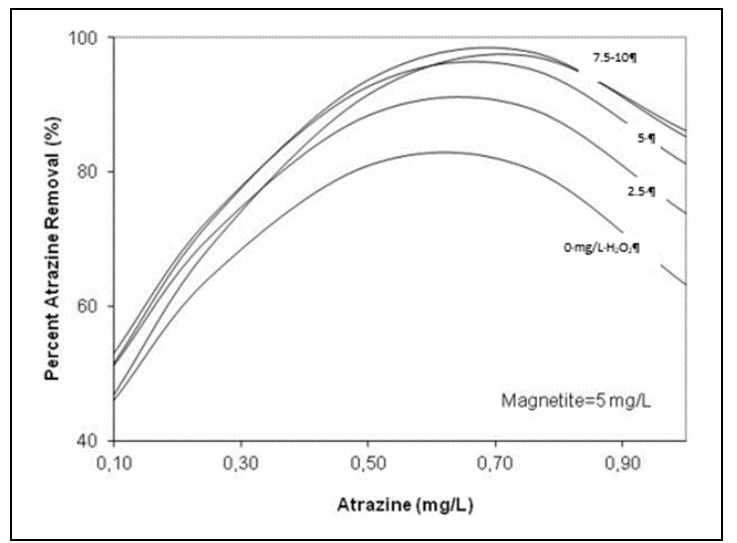

Figure 3: Atrazine removal efficiencies achieved with different atrazine and $\mathrm{H}_{2} \mathrm{O}_{2}$ concentrations (Magnetite: $5 \mathrm{mg} / \mathrm{L}$. Reaction. Reaction time:60 min. pH:3.5).

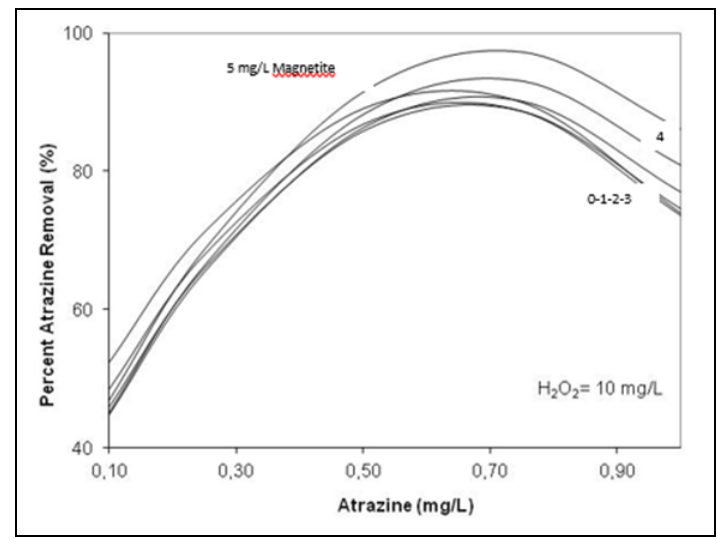

Figure 4: Atrazine removal efficiencies achieved with different atrazine and Magnetite concentrations $\left(\mathrm{H}_{2} \mathrm{O}_{2}: 10 \mathrm{mg} / \mathrm{L}\right.$. Reaction time:60 min. $\mathrm{pH}: 3.5)$.

Atrazine degradation was completely achieved with $\mathrm{H}_{2} \mathrm{O}_{2}$ concentration of $7.5 \mathrm{mg} / \mathrm{L}$ and magnetite concentration of 5 $\mathrm{mg} / \mathrm{L}$ during $60 \mathrm{~min}$ reaction time. However, atrazine degradation was affected by initial atrazine concentration. Atrazine removal efficiencies were 98 and $85 \%$ when initial atrazine concentration of $0.7 \mathrm{mg} / \mathrm{L}$ and $1 \mathrm{mg} / \mathrm{L}$, respectively, at $\mathrm{H}_{2} \mathrm{O}_{2}$ concentration of $7.5 \mathrm{mg} / \mathrm{L}$ and magnetite concentration of $5 \mathrm{mg} / \mathrm{L}$. According to initial atrazine concentration, optimum oxidant, catalyst dose should be determined by statically design program in order to optimum molar ratio to achieve sufficient atrazine removal.

At high atrazine doses such as $0.7 \mathrm{mg} / \mathrm{L}$, atrazine degradation was completely occurred with higher $\mathrm{H}_{2} \mathrm{O}_{2}$ and magnetite doses. In other words, molar ratio of oxidant to catalyst is very important parameter. Above $0.7 \mathrm{mg} / \mathrm{L}$ atrazine concentration, molar ratio of hydrogen peroxide to magnetite was in sufficient. When inadequate amount of $\mathrm{H}_{2} \mathrm{O}_{2}$ or magnetite are used, complete atrazine degradation did not observe during reaction time (one hour). At molar ratio of 2 , approximately $45 \%$ atrazine removal efficiency was obtained at $0.1 \mathrm{mg} / \mathrm{L}$ initial atrazine concentration due to excess oxidant and catalyst dose. Insufficient removal efficiencies were achieved by high molar ratio. Most important issue for atrazine treatment is to evaluate molar ratio of oxidant and catalyst. So, optimum reaction conditions should be arranged by means of statically design approach according to initial atrazine concentration.

As can be shown in Figure 4, atrazine removal efficiencies were $47,97.5$ and $86 \%$ when initial atrazine concentrations of $0.1,0.7$ and $1 \mathrm{mg} / \mathrm{L}$ respectively at a magnetite concentration of $5 \mathrm{mg} / \mathrm{L}$ and at a $\mathrm{H}_{2} \mathrm{O}_{2}$ concentration of $10 \mathrm{mg} / \mathrm{L}$. When magnetite concentration decreased to $1 \mathrm{mg} / \mathrm{L}$, percent atrazine removals was $48.3,89.6$ and $73.5 \%$ when initial atrazine concentrations of $0.1,0.5$ and $1 \mathrm{mg} / \mathrm{L}$, respectively. As can be shown in Figure 4, atrazine degradation was not completely achieved with low magnetite concentration. This phenomenon also observed at low $\mathrm{H}_{2} \mathrm{O}_{2}$ concentration due to insufficient concentration of oxidant and catalyst to produce $\bullet \mathrm{OH}$ radicals.

Results of atrazine removal by means of different oxidant and catalyst dose are given in Figure 5 as 3D format. Atrazine removal efficiencies can be clearly presented and evaluated in this format. After evaluation of experiments, it can be said that the optimum $\mathrm{H}_{2} \mathrm{O}_{2}$ /Magnetite/Atrazine concentration producing the highest atrazine removal efficiency $(50 \%)$ was $5 / 5 / 0.1$ at low atrazine dose of $0.1 \mathrm{mg} / \mathrm{L}$, while this molar ratio was $10 / 5 / 1$ producing $86 \%$ atrazine removal efficiency at a high atrazine dose of $1 \mathrm{mg} / \mathrm{L}$.

The analysis of variance showed that all variables (atrazine, $\mathrm{H}_{2} \mathrm{O}_{2}$ and magnetite) and the interactions $\left(\mathrm{X}_{1} \mathrm{X}_{2}, \mathrm{X}_{1} \mathrm{X}_{3}, \mathrm{X}_{2} \mathrm{X}_{3}, \mathrm{X}_{1}{ }^{2}\right.$, $\mathrm{X}_{2}{ }^{2}$ ) were significant. All independent variables are important and affect the atrazine degradation by heterogeneous PhotoFenton like oxidation as mentioned in Table 5.

When the $\mathrm{H}_{2} \mathrm{O}_{2}$ concentration is increased to $5 \mathrm{mg} / \mathrm{L}$ from 0 $\mathrm{mg} / \mathrm{L}$, oxidation process is converted to $\mathrm{UV} / \mathrm{H}_{2} \mathrm{O}_{2} /$ Magnetite process from UV/Magnetite process. Atrazine treatment yield increases to $95 \%$ from $80 \%$ by means of changing oxidation process. Process variation is important in the treatment of atrazine and $\mathrm{UV} / \mathrm{H}_{2} \mathrm{O}_{2}$ /Magnetite process which is a modification of two processes instead of using $\mathrm{UV} / \mathrm{H}_{2} \mathrm{O}_{2}$ process or UV/Magnetite process, is found to be more effective.

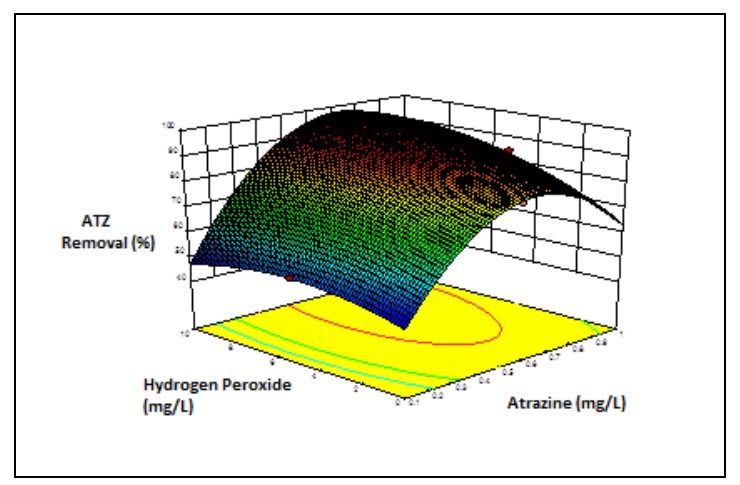

Figure 5: Atrazine removal efficiencies achieved with different atrazine and $\mathrm{H}_{2} \mathrm{O}_{2}$ concentrations (Magnetite: $5 \mathrm{mg} / \mathrm{L}$, Reaction time: $60 \mathrm{~min}, \mathrm{pH}: 3.5)$.

\section{Conclusion}

Heterogeneous photo-Fenton like oxidation as an advanced oxidation process was applied to atrazine in order to degrade. In order to optimize reaction conditions in advanced oxidation process, statically design approach used. The most useful response surface methodology is Box-Behnken statistical design which was used for this aim. Atrazine, $\mathrm{H}_{2} \mathrm{O}_{2}$ and 
magnetite concentrations were chosen as independent variables while atrazine removal efficiency was selected as dependent variable (objective function).

Atrazine removal efficiency decreases with initial atrazine concentration $\left(\mathrm{X}_{1}\right)$ while increasing with the $\mathrm{H}_{2} \mathrm{O}_{2}$ concentration $\left(\mathrm{X}_{2}\right)$ and magnetite concentrations $\left(\mathrm{X}_{3}\right)$. The $\mathrm{H}_{2} \mathrm{O}_{2}$ variable has a more significant effect on atrazine removal efficiency when compared to magnetite independent variables. Dose of independent variables has significant effect on dependent variables or objective function. Atrazine removal efficiency (nearly 95\%) was achieved by heterogeneous Photo-Fenton like oxidation process. In advanced oxidation process, the highest atrazine removal efficiency (97.5\%) was obtained with a $\mathrm{H}_{2} \mathrm{O}_{2}$ /Magnetite/Atrazine ratio of $10 / 5 / 0.7 \mathrm{mg} / \mathrm{L}$. The optimum oxidant and catalyst doses changed with the initial atrazine concentrations. In addition, kind of process is also important in the treatment of atrazine and $\mathrm{UV} / \mathrm{H}_{2} \mathrm{O}_{2} /$ Magnetite process, which is a modification of two processes instead of using $\mathrm{UV} / \mathrm{H}_{2} \mathrm{O}_{2}$ process or $\mathrm{UV} /$ Magnetite process, is found to be more effective. In future studies, real wastewater samples should be used to observe effectiveness of this process and operating costs may be calculated and compared each other.

\section{References}

[1] Martin-Neto L, Traghetta DG, Vaz P, Crestana S, Sposito G. "On the interaction mechanisms of atrazine and hydroxyatrazine with humic substances". Journal of Enviromental Quality, 2, 520-525, 2001.

[2] Chan K.H, Chu W. "Model applications and mechanism study on the degradation of atrazine by Fenton's system". Journal of Hazardous Materials, 118(1-3), 227-237, 2005.

[3] Murphya MB, Hecker M, Coady KK, Tompsettb AR, Jones D, Du Preez LH. "Atrazine concentrations, gonadal gross morphology and histology in ranid frogs collected in Michigan agricultural areas". Aquatic Toxicology, 76, 230-45, 2006.

[4] Dehghani M, Nasseri N, Amin SA, Zamanian Z. "Assessment of atrazine distribution in Shiraz soils, South of Iran". Pakistan Journal of Biological Science, 13(2), 66-72, 2010.

[5] Benzaquen T, Benzzo M, Isla M, Alfano O. "Impact of some herbicides on the biomass activity in biological treatment plants and biodegradability enhancement by a photo-Fenton process". Water Science Technology, 67, 210-216, 2013.

[6] Ribeiro A, Nunes O, Pereira M, Silva A. "An overview on the advanced oxidation processes applied for the treatment of water pollutants defined in the recently launched Directive 2013/39/EU". Enviromental Inernational, 75, 33-51, 2015.
[7] Klamerth N, Miranda N, Malato S, Aguera A, FernandezAlba A, Maldonado M, Coronado J. "Degradation of emerging contaminants at low concentrations in MWTPs effluents with mild solar photo-Fenton and $\mathrm{TiO}_{2}$ ". Catalytic Today, 144, 124-130, 2009.

[8] Maldonado M, Passarinho P, Oller I, Gernjak W, Fernandez P, Blanco J, Malato S. "Photocatalytic degradation of EU priority substances: a comparison between $\mathrm{TiO}_{2}$ and Fenton plus photo-Fenton in a solar pilot plant". Journal of Photochemical and Photobiology A: Chemistry, 185, 354-363, 2007.

[9] Perez M, Penuela G, Maldonado M, Malato O, FernandezIbanez P, Oller L, Gernjak W, Malato S. "Degradation of pesticides in water using solar advanced oxidation processes". Applied Catayst, B. 64, 272-281, 2006.

[10] Hou L, W. Zhang Q, Jerome HF, Duprez D, Zhang H, Royer S. "Shape-controlled nanostructured magnetite-type materials as highly efficient Fenton catalysts". Applied Catalyst, B. 144, 739-749, 2014.

[11] Cornell RM, Schwertmann U. The Iron Oxides: Structure, Properties, Reactions Occurrences, and Uses. $2^{\text {nd }}$ ed. Newyork, USA, Wiley, 2003.

[12] Boza A, De La Cruz Y, Jordan G, Jauregui-Haza U, Aleman A, Caraballo I. "Statistical optimization of a sustainedrelease matrix tablet of lobenzarit disodium". Drug Devolepment and Industrial Pharmacy, 26, 1303-1307, 2000.

[13] Box GEP, Wilson KB. "On the experimental attainment of optimum multifactorial conditions". Royal Statistics Society, 13, 1-12, 1951.

[14] Singh SK, Dodge J, Durranı MJ, Khan MA. "Optimization and characterization of controlled release pellets coated with an experimental latex: I. Anionic drug". International Journal Pharmacy, 125, 243-255, 1995.

[15] Sastry SV, Khan MA. "Aqueous based polymeric dispersion: Plackett-Burman design for screening of formulation variables of atenolol gastrointestinal therapeutic system". Pharm Acta Helvetiae, 73, 105-112, 1998.

[16] Hamed E, Sakr A. "Application of multiple response optimization technique to extended release formulations design". Journal of Control Release, 73, 329-338, 2001.

[17] Glaze WH, Kang J, Lay Y. "Advanced oxidation processes. A kinetic model for the oxidation of 1,2-dibromo-3chloropropane in water by the combination of hydrogen peroxide and UV radiation". Industrial Engineering Chemical Research, 34, 2314-2323, 1995.

[18] Beltran FJ, Ovejero G, Rivas J. "Oxidation of polynuclear aromatic hydrocarbon in water by UV radiation in combination with hydrogen peroxide". Industrial Engineering Chemical Research, 35, 883-889, 1996. 